\title{
A Survey on Cloud Providers and Migration Issues
}

\author{
Neetika Gupta \\ Amity University \\ Noida, Uttar Pradesh
}

\author{
Jyoti Kataria \\ Amity University \\ Noida, Uttar Pradesh
}

\author{
Abhay Bansal, PhD. \\ Amity University \\ Noida, Uttar Pradesh
}

\begin{abstract}
From the most promising area of networking, the concept of using the services of cloud computing is on a great consideration nowadays. As a result it's a crucial time for corporate IT leaders to know their opportunities, innovating their creations on a higher level and utilizing their resources for new great challenges. Cloud computing potentially aims in making an organization more agile and cost effective. Keeping in way all the advantages that a cloud accommodates in its working, still the decision makers have a difficult eye on 'how' and 'why' to adopt cloud. This paper discusses some of the important concerns that a corporate developer might have before radically shifting to use the services provided by the cloud and also gives an enlighted solutions to those concerns.
\end{abstract}

\section{Keywords}

Cloud Computing, Virtualization, Cloud Migration, Cloud Providers, Research Group.

\section{INTRODUCTION}

Cloud Computing is a simple way of creating and delivering compute resources. However as said that "Cloud computing is an evolving paradigm." [1], the sources of benefits that are taken into view by the decision makers while assessing the feasible adoption of cloud computing can be listed as:-

- Ease of cash-flow management.

- Opportunities to offer new products and services.

- Rapid Organization growth.

- Improved status of the technology used.

- Improved satisfaction of work.

In September 2011, the National Institute of Standards and Technology (NIST) released Special Publication SP 800-145, in which it defined cloud computing as:- "Cloud computing is a model for enabling ubiquitous, convenient, on-demand network access to a shared pool of configurable computing resources (e.g., networks, servers, storage, applications, and services) that can be rapidly provisioned and released with minimal management effort or service provider interaction. This cloud model is composed of five essential characteristics, three service models, and four deployment models. "[1]

But along with these open minded advantages of shared resources and virtualization, comes risks that cause a degree of confusion in utilizing a cloud environment over a traditional in-house data center. Some of the risks that were studied when an enterprise IT system was migrated to IaaS (Infrastructure as a service) [2] were:-

- Deterioration of customer care \& service quality.

- Decrease in satisfaction.

- Departmental downsizing.
- Uncertainty with new technology.

- $\quad$ Lack of supporting resources.

- $\quad$ Lack of understanding of the cloud.

So, while making a cloud a boon or curse for your organization, it's important to figure out the type of cloud you want to work with and who will be the provider. The deployment of cloud could be done in three ways:-

Public cloud here the cloud computing service providers (CCSPs) use public internet or WAN to provide the services which could be prevailed by different organizations.

Private cloud where centralization of all the servers of an organization to one of its data center is done within the same IT environment. Moreover no sharing of physical servers and networking resources is made.

Hybrid cloud According NIST [3], "Hybrid cloud is a composition of two or more clouds (private, public or community) that remains unique entities but are bound together, offering the benefits of multiple deployment models. Extending its explanation it can also be defined as a connection of various clouds that permits the movement of data easily from one deployment system to another.

\section{PARAMETERS: CLOUD COMPUTING}

These parameters may be considered in understanding the solutions that are provided by cloud computing. As, besides weighing the factors that lists the benefits and risks from cloud provider, one should also weigh the value against traditional in-house data center and hosting options. Therefore, on priority measurement, parameters must be framed.

Table 1: Parameters providing understanding of the solutions provided by cloud computing

\begin{tabular}{|c|c|}
\hline Parameters & \\
\hline Centralization & $\begin{array}{l}\text { Keeping the application resources and } \\
\text { data stored at a central location }\end{array}$ \\
\hline Virtualization & $\begin{array}{l}\text { Virtualization is a key technology } \\
\text { underlying cloud computing platforms } \\
\text { [4], where applications encapsulated } \\
\text { within virtual machines are dynamically } \\
\text { mapped onto a pool of physical servers. }\end{array}$ \\
\hline
\end{tabular}




\begin{tabular}{|c|c|}
\hline $\begin{array}{l}\text { Automation and } \\
\text { Orchestration }\end{array}$ & $\begin{array}{l}\text { The capacity of dynamic virtualized } \\
\text { services can be automated eradicating } \\
\text { the manual tasks involved in their } \\
\text { management. }\end{array}$ \\
\hline $\begin{array}{l}\text { Dynamic creation } \\
\text { and movement of } \\
\text { resources }\end{array}$ & $\begin{array}{l}\text { The resources are made available } \\
\text { dynamically "anywhere anytime" }\end{array}$ \\
\hline Network & $\begin{array}{l}\text { In order to support cloud computing, a } \\
\text { cloud network must be dramatically } \\
\text { more agile and cost effective than a } \\
\text { traditional network.[5] }\end{array}$ \\
\hline Self Service & $\begin{array}{l}\text { Self-Service to allow end users to select } \\
\text { and modify their use of IT resources } \\
\text { without the IT organizations being an } \\
\text { intermediary. }\end{array}$ \\
\hline $\begin{array}{l}\text { Usage sensitive } \\
\text { chargeback }\end{array}$ & i.e. pay-as-you-go. \\
\hline Simplification & $\begin{array}{l}\text { Applications and the services provided } \\
\text { by the IT are simplified. }\end{array}$ \\
\hline Standardization & $\begin{array}{l}\text { The development of standards of IT } \\
\text { infrastructure }\end{array}$ \\
\hline $\begin{array}{l}\text { Technology } \\
\text { Convergence }\end{array}$ & $\begin{array}{l}\text { Such as convergence of LAN and SAN } \\
\text { and of switch and server. }\end{array}$ \\
\hline Multi-Tenancy & $\begin{array}{l}\text { Applications hosted within a cloud are } \\
\text { accessible to multi-users at the same } \\
\text { time. }\end{array}$ \\
\hline
\end{tabular}

A survey conducted by "Cloud Computing: A Reality Check and Guide to Risk Mitigation" [6] imprinted the responses of survey respondents, listing the factors driving, or would likely drive their company to cloud computing services. Their responses were figured as:-

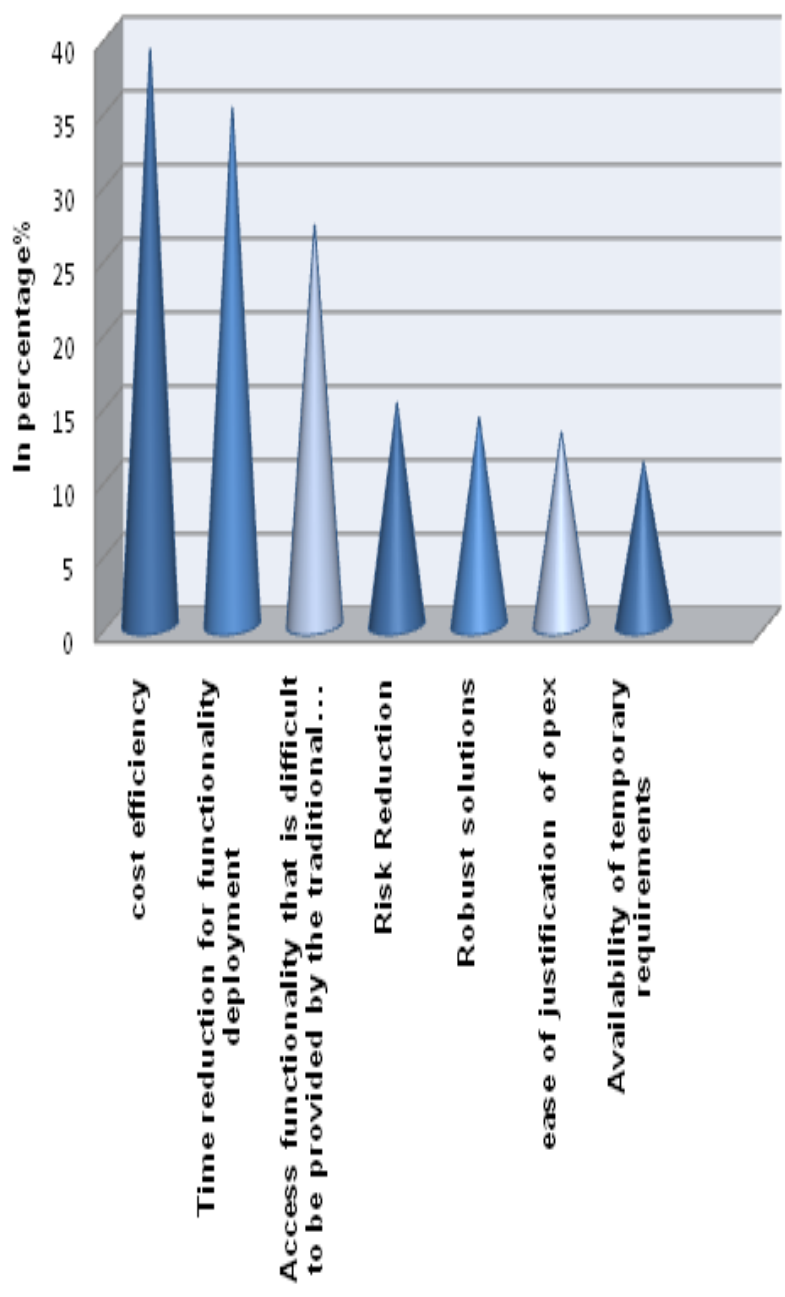

Figure 1. Drivers of Cloud Computing Service

Andrew McAfee, in his report "What Every CEO Needs to Know About The Cloud" [7] stated that when an organization decides to use the cloud services, it should first start running experiments with SaaS (Software as a service) and then gradually shifting to developing the applications on cloud. Cloud computing surely has various surprising advantages but eventually the transformation should be lead by the right people.

\section{CLOUD COMPUTING PROVIDERS}

Today, in this era where everybody is fighting to earn best, it's hard to identify the provider that could know the specifications with a perfect understanding and offering the best solutions. Therefore, before choosing the provider, it's important for an 
Table 2: Top 10 ranked Cloud provide

\begin{tabular}{|c|c|c|c|}
\hline RANK & $\begin{array}{l}\text { Cloud Computing Service } \\
\text { Provider }\end{array}$ & About The CCSPs & $\begin{array}{l}\text { Top } \\
\text { Executive }\end{array}$ \\
\hline 1. & $\begin{array}{l}\text { Amazon Web Services, Seattle, } \\
\text { WA, USA }\end{array}$ & $\begin{array}{l}\text { Amazon Web Services (AWS) launched in } 2006 . \\
\text { Amazon has data centers in the U.S., Europe, } \\
\text { Singapore, and Japan. }\end{array}$ & $\begin{array}{l}\text { Jeff Bezos, } \\
\text { CEO }\end{array}$ \\
\hline 2. & $\begin{array}{l}\text { Rackspace, San Antonio, TX, } \\
\text { USA }\end{array}$ & $\begin{array}{l}\text { Rackspace's cloud services launched as Mosso in } \\
\text { 2006. Company revenues now exceed \$1 billion. }\end{array}$ & $\begin{array}{l}\text { Lanham } \\
\text { Napier, CEO }\end{array}$ \\
\hline 3. & $\begin{array}{l}\text { Savvis (CenturyLink), Town \& } \\
\text { Country, MO, USA }\end{array}$ & $\begin{array}{l}\text { CenturyLink company, Savvis has } 50 \text { data centers } \\
\text { (with more than } 1.5 \text { million square feet) in North } \\
\text { America, Europe, and Asia. }\end{array}$ & $\begin{array}{l}\text { Jim Ousley, } \\
\text { CEO }\end{array}$ \\
\hline 4. & Equinix, Redwood City, CA, USA & $\begin{array}{l}\text { Equinix connects more than } 4,000 \text { enterprises, cloud, } \\
\text { digital content and financial companies }\end{array}$ & $\begin{array}{l}\text { Stephen } \\
\text { Smith, CEO }\end{array}$ \\
\hline 5. & $\begin{array}{l}\text { NaviSite (Time Warner), } \\
\text { Andover, MA, USA }\end{array}$ & $\begin{array}{l}\text { NaviSite provides cloud-enabled hosting, managed } \\
\text { applications and services.. }\end{array}$ & $\begin{array}{l}\text { R. Brooks } \\
\text { Borcherding, } \\
\text { President }\end{array}$ \\
\hline 6. & $\begin{array}{l}\text { Computer Services Inc., Paducah, } \\
\text { KY, USA }\end{array}$ & $\begin{array}{l}\text { SI is one of the largest service providers focused on } \\
\text { financial institutions, with an emphasis on compliance } \\
\text { monitoring }\end{array}$ & $\begin{array}{l}\text { Steve } \\
\text { Powless, CEO }\end{array}$ \\
\hline 7. & SoftLayer, Dallas, TX, USA & $\begin{array}{l}\text { With } 100,000 \text { servers under mangement, SoftLayer } \\
\text { claims to be the largest privately held IaaS provider in } \\
\text { the world. }\end{array}$ & $\begin{array}{l}\text { Lance Crosby, } \\
\text { CEO }\end{array}$ \\
\hline 8. & $\begin{array}{l}\text { Layered Technologies, Plano, TX, } \\
\text { USA }\end{array}$ & $\begin{array}{l}\text { Layered Technologies focuses on compliance-based } \\
\text { cloud services, having acquired FastServers.net } \\
\text { (managed hosting) and GreenSoft Solutions (PCI } \\
\text { compliance) in } 2010\end{array}$ & $\begin{array}{l}\text { Jack } \\
\text { Finlayson, } \\
\text { CEO }\end{array}$ \\
\hline 9. & $\begin{array}{l}\text { LogicWorks, New York, NY, } \\
\text { USA }\end{array}$ & $\begin{array}{l}\text { Logicworks provides cloud computing and managed } \\
\text { hosting to Dow Jones, Lincoln Center for the } \\
\text { Performing Arts, Orion Health }\end{array}$ & $\begin{array}{l}\text { Ken Ziegler, } \\
\text { CEO }\end{array}$ \\
\hline 10. & Apptix, Herndon, VA, USA & $\begin{array}{l}\text { Apptix hosted services support more than } 350000 \text { users } \\
\text { around the world. The company's core focus includes } \\
\text { hosted Exchange VoIP, SharePoint, Web } \\
\text { Conferencing, and Secure IM with Presence. }\end{array}$ & $\begin{array}{l}\text { David } \\
\text { Ehrhardt, } \\
\text { CEO }\end{array}$ \\
\hline
\end{tabular}

organization to formulate its demands and expectations. To do this, one should have a detailed knowledge about the Cloud Computing Service Providers (CCSPs) and their offerings. A recent January-April 2012 survey done by “The Talkin' Cloud 100 survey "[8] listed 100 CCSPs and ranked them in order of the quality of service they provide. The list of top 10 CCSPs working across the globe is given in Tabel2.
Apart from these cloud providers there are a lot working forums and research groups working in order to provide highly demanded offerings for organizations. Cloud

Computing offers supercomputer's like high performance but to avail such a performance one needs to work on a correct domain and with a correct provider 


\section{RESEARCH GROUPS}

There are various leading research groups working towards making providing better solutions through cloud.

\section{Table 3: Research Groups}

\begin{tabular}{|c|c|c|}
\hline S.No. & $\begin{array}{l}\text { Research } \\
\text { Group }\end{array}$ & Work \\
\hline 1. & $\begin{array}{l}\text { The Internation } \\
\text { al Working } \\
\text { Group on } \\
\text { Cloud } \\
\text { Computing } \\
\text { Resiliency } \\
\text { (IWGCR) }\end{array}$ & $\begin{array}{l}\text { Telecom ParisTech formed this } \\
\text { group in March, } 2012 \text {. IWGCR } \\
\text { along with Paris } 13 \text { University } \\
\text { published the first Availability } \\
\text { Ranking of World Cloud } \\
\text { Computing (ARWC) on June } \\
18,2012 \text {. }\end{array}$ \\
\hline 2. & $\begin{array}{l}\text { ITU-T Focus } \\
\text { Group on } \\
\text { Cloud } \\
\text { Computing (FG } \\
\text { Cloud) }\end{array}$ & $\begin{array}{l}\text { Was established further to ITU- } \\
\text { T TSAG agreement at its } \\
\text { meeting in Geneva, } 8-11 \\
\text { February } 2010 \text { followed by } \\
\text { ITU-T study groups and } \\
\text { membership consultation. It } \\
\text { was successfully concluded in } \\
\text { December } 2011 \text {. }\end{array}$ \\
\hline 3. & $\begin{array}{l}\text { The } \\
\text { International } \\
\text { Working Group } \\
\text { on Data } \\
\text { Protection in } \\
\text { Telecommunic } \\
\text { ations, the so- } \\
\text { called "Berlin } \\
\text { Group" }\end{array}$ & $\begin{array}{l}\text { Aims in making public cloud } \\
\text { more trustworthy by } \\
\text { implementing privacy using } \\
\text { design technologies and legal } \\
\text { guidance. For achieving this } \\
\text { they support projects like } \\
\text { TClouds. The group has also } \\
\text { published a working paper on } \\
\text { cloud computing in the wake of } \\
\text { its } 51 \text { st meeting in Sopot } \\
\text { (Poland) }\end{array}$ \\
\hline 4. & $\begin{array}{l}\text { Ian } \\
\text { Sommerville }\end{array}$ & $\begin{array}{l}\text { Projects } \\
\text { - } \quad \text { Cloud computing for } \\
\text { Large-Scale Complex IT } \\
\text { Systems_(2010-13). } \\
\text { - } \quad \text { Services to the } \\
\text { Cloud (2011-13) } \\
\text { - } \quad \text { Elastic Virtual } \\
\text { Infrastructure for Research } \\
\text { Applications (ELVIRA) } \\
\text { (2011) }\end{array}$ \\
\hline 5. & Gartner & $\begin{array}{l}\text { Focuses on Big Data, Smart } \\
\text { Devices, Cloud Computing, } \\
\text { Maturing As Technologies, } \\
\text { BOYD Rises. Recently } \\
\text { published a report on" Hype } \\
\text { Cycle for emerging } \\
\text { technologies 2012" }\end{array}$ \\
\hline
\end{tabular}

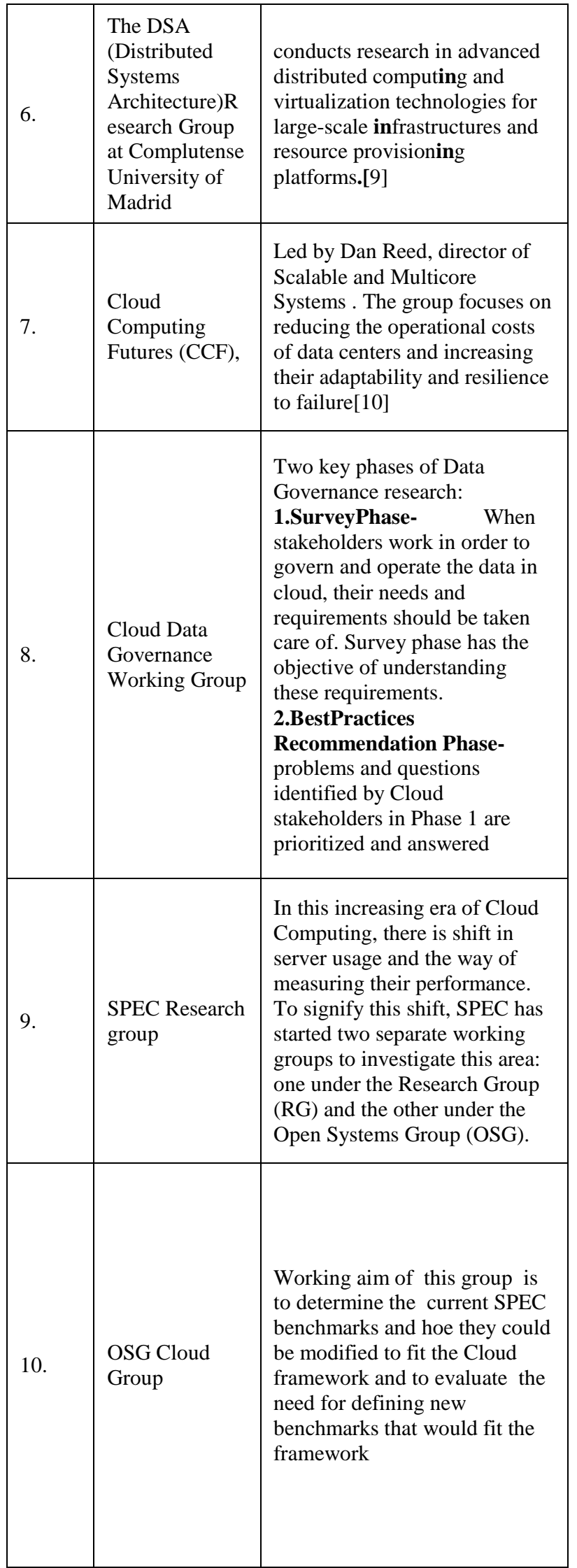




\begin{tabular}{|c|c|c|}
\hline 11. & $\begin{array}{l}\text { RG Cloud } \\
\text { Group }\end{array}$ & $\begin{array}{l}\text { Focuses on developing notified } \\
\text { benchmarks (referred as } \\
\text { research benchmarks)that are } \\
\text { intended to be used for } \\
\text { understanding Cloud behavior } \\
\text { and performance on a larger } \\
\text { perspective, and may not } \\
\text { necessarily be standardized } \\
\text { through the SPEC process. } \\
\text { Therefore, it's a broader } \\
\text { approach relevant for both } \\
\text { academic and industry. [11] }\end{array}$ \\
\hline 12. & $\begin{array}{l}\text { Future } \\
\text { Computing } \\
\text { Group }\end{array}$ & $\begin{array}{l}\text { For many years the group has } \\
\text { been working on Grid/Cloud } \\
\text { Computing (Internet II), Green } \\
\text { Computing, and Virtual } \\
\text { Computing. The group targets } \\
\text { the applications and working of } \\
\text { next generation computing } \\
\text { paradigms. One of its projects, } \\
\text { a developed Grid/Cloud } \\
\text { Computing platform conforms } \\
\text { to the Internet standard and can } \\
\text { universally accelerate } \\
\text { Office/Database/Web/Media } \\
\text { applications by a factor up to } \\
\text { ten. This work won an } \\
\text { ACM/IEEE Super Computing } \\
\text { Finalist Award.[12] }\end{array}$ \\
\hline 13. & $\begin{array}{l}\text { StACC - } \\
\text { Collaborative } \\
\text { Research in } \\
\text { Cloud } \\
\text { Computing }\end{array}$ & $\begin{array}{l}\text { Is a research collaboration, } \\
\text { launched in April } 2009 \text { focusing } \\
\text { on research in the important } \\
\text { new area of cloud computing. } \\
\text { Unique in the UK, StACC aims } \\
\text { to become an international } \\
\text { centre of excellence for } \\
\text { research and teaching in cloud } \\
\text { computing and will provide } \\
\text { advice and information to } \\
\text { businesses interested in using } \\
\text { cloud-based services.[13] }\end{array}$ \\
\hline
\end{tabular}

\section{IMPACT}

Talking about the impact that Cloud has on today's organizations, we may walk along a survey done by "Cloud Computing in India", A CIO Research Center Report [14]. It was spotted that only IT/ITes share the largest industry area responding to the queries about adopting the cloud services, Figure2.

And within their key findings, only $54 \%$ of CIOs have evaluated Cloud Computing and $46 \% \mathrm{CIO}$ s have yet to evaluate cloud computing, Figure 3. Cloud results are remarkably measurable and satisfactory from most of the users so far. As rated by the

IBM report "Making Cloud Computing Safe" [15], the capability of cloud to utilize sever/storage space has increased from $10-20 \%$ to $70-90 \%$ and today self verified standards could also be attained.

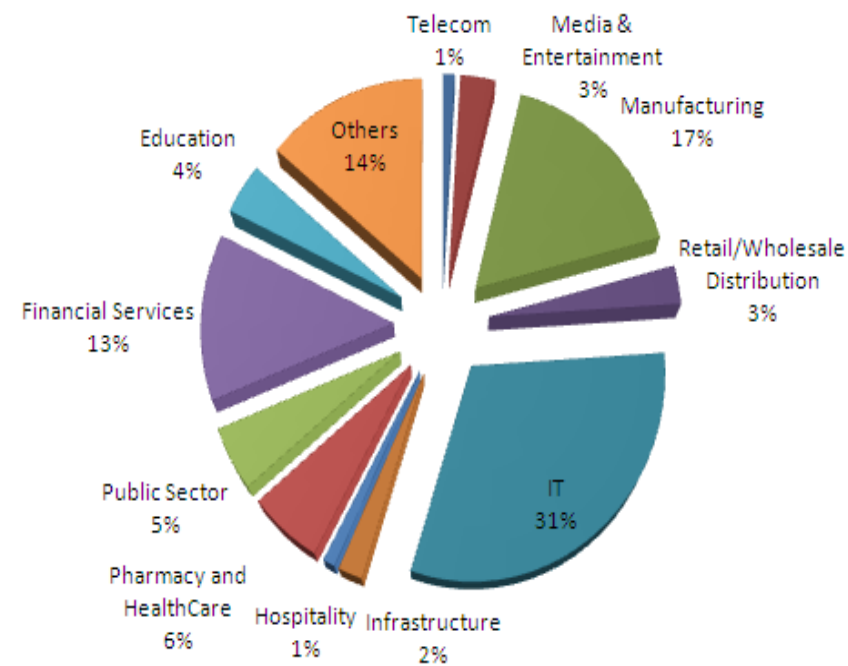

Figure 2. Response from various industries across the globe

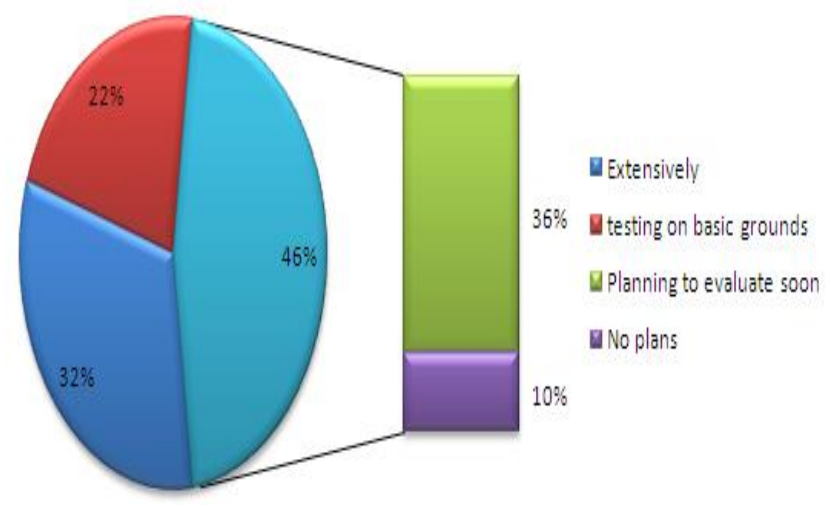

Figure 3. Evaluation of cloud computing by organizations

While continuing to work on such paradigms, cloud computing has been termed as a disruptive technology that aims in deploying a way of computing that is cheaper and is most importantly, scalable. However, cloud computing could potentially eradicate many machine- maintenance-related issues as there would be no physical infrastructure to maintain.

Despite of all such advantages, organizations still think twice or a hundred times while transferring their operations and workload to cloud. Keeping data security and privacy the primary factors, there are various more listed parameters that come forward as barriers to cloud adoption, Figure 4. 


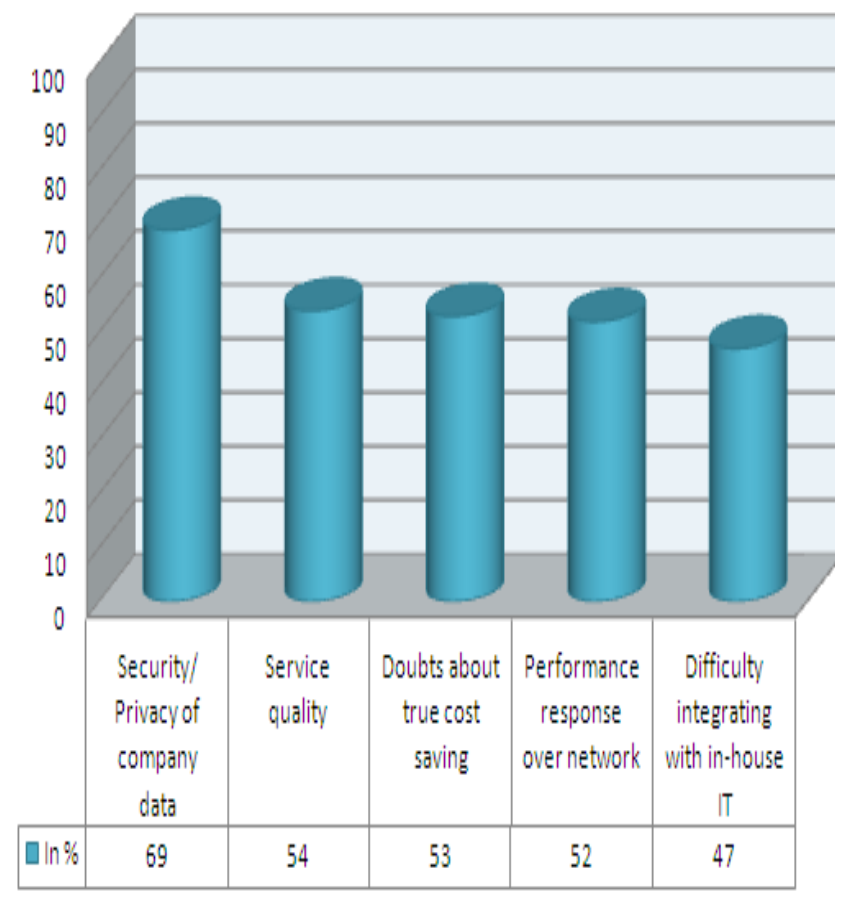

Figure 4. Rated barriers

Cloud Migration can also be supported by a set of analysis as referred by "Cloud Adoption Toolkit" [16] that talks about Technology Suitability Analysis, Energy Consumption Analysis, Stakeholder Impact Analysis, Responsibility Modeling and Cost Modeling. These steps could also help the decision framers during the adoption of cloud in the enterprise.

\section{CONCLUSION}

Cloud migration, when comes to an actual implementation becomes a hideous task for the decision makers to reach to a profit making and a perfect solution. The paper discusses the work of various cloud providers and research groups that are working ahead in adding the advantages of cloud services. Inspite of all the progress and technology enhancements that cloud computing brings, enterprises still face some challenging problems while reaching to a decision of whether to or not to adopt cloud. Studying the applicability of cloud in various systems is a vast research challenge and also adoption of cloud needs to overlook some of the loopholes that cloud brings along but surely these loopholes couldn't be eradicated; they could only be reduced by picking the right solution and the right provider. Therefore, awareness needs to be lightened up among enterprises, making them understand what profits cloud can actually bring to their revenues and working environment.

In supporting these challenges or in other words, finding solutions to understand the pros \& cons of cloud adoption for an organization, some techniques could be introduced in future, for example, the "Cloud Adoption Toolkit" [16], that focused on cost modeling and described the challenges associated with it. Similarly on the basis of some important parameters, such toolkits could be designed to make the decision making an easier job for the developers.

\section{REFERENCES}

[1] National Institute of Standards and Technology (NIST), Special Publication 800-145, The NIST Definition of Cloud Computing, September 2011

[2] Ali Khajeh-Hosseini,David Greenwood, Ian Somerville , Cloud Computing Co-laboratory School of Computer Science University of St Andrews, UK "Cloud Migration: A Case Study of Migrating an Enterprise IT System to IaaS"

[3] "The NIST Definition of Cloud Computing "Recommendations of the National Institute of Standards and Technology, Peter Mell \&Timothy Grance

[4] Amazon Elastic Compute Cloud (EC2). http://aws. amazon.com/ec2/.

[5] "The 2010 Cloud Networking Report" by Dr. Jim Metzler Ashton Metzler \& Associates, Webtorials Analyst Division

[6] "Cloud Computing: A Reality Check \& Guide to Risk Mitigation "Webtorials State-of-the-Market Report by Jim Metzler, Cofounder, Webtorials Editorial/Analyst Division

[7] "What Every CEO Needs to Know About The Cloud" by Andrew McAfee, article originally appeared in Harvard Business Review (reprint \#R1111J).

[8] Top 100 Cloud Services Providers (CSPs) List And Research, http://www.talkincloud.com/tc100/

[9] Dsa-Research.org http://dsa-research.org/doku.php

[10] Peering into Future of Cloud Computing http://research.microsoft.com/en-us/news/features/ccf022409.aspx

[11] RG Cloud Group http://research.spec.org/workinggroups/rg-cloud-working-group.html

[12] FutureComputingGroup http://www.cs.kent.ac.uk/research/groups/future/

[13] StACC - Collaborative Research in Cloud Computinghttp://www.cs.st-andrews.ac.uk/stacc

[14] "Cloud Computing in India" A CIO Research Center Report, Supported by MICROSOFT

[15] "Making Cloud Computing Safe Trust, security, resiliency, availability and complexity "Donald Kneitel IBM Global Technology Services.

[16] "The Cloud Adoption Toolkit: Supporting Cloud Adoption Decisions in the Enterprise "Ali KhajehHosseini, David Greenwood, James W. Smith, Ian Sommerville Cloud Computing Co-laboratory, School of Computer Science University of St Andrews, UK 